


\section{Applying the \\ Burden of Proof and Creating Connections to Communities}

\section{Patricia Cochran ${ }^{\star}$}

One of the questions that lies at the heart of the Insite case $\mathrm{e}^{1}$ is this: what kind of connections should exist between the law and the people it governs? In this short comment, I explore one of the ways this question informs the treatment of evidence and proof by focusing on the section 7 aspect of the case and the question of arbitrariness. With the goal of inviting discussion, I suggest that in cases involving the constitutional rights of marginalized individuals and communities, the concept of the "burden of proof" can provide a way to help understand what is at stake, and what criteria we might use to relate the burden of proof to values of equality and justice.

The idea of a "connection" between law and its communities can be understood in a very broad sense, reflecting the way questions of jurisdiction and human rights speak to the boundaries of communities and their relationship to legal rules. Peoples' overlapping membership in local, social, medical, regional, national and other groups are all at play in the Insite case, and the various judgments all attempt to grapple with the significance of these communities for the legal questions at issue. The questions of "connections" in this sense are addressed by constitutional law, which helps determine what kind of connections are required, for example, in order for a law to be non-arbitrary.

The notion of "connection" can also be understood in an evidentiary sense. In this sense, questions of connection are about determining what will count as adequate grounds for legal and factual claims. Once we understand what kind of connections are required by the substantive law, it is necessary to ask: how do we know when these connections exist? Can the "connection" be established by logic? By scientific expertise? By the recounting of personal experience? What is the significance of community consensus? Of legislative intent?

The significance of this type of connection - an evidentiary connection - appears in relation to multiple legal questions in Insite. For example, to support her use of the doctrine of interjurisdictional immunity to protect the legal existence of the safe injection site, Huddart JA cites the requirement that constitutional law must "remain responsive to the $a c$ tual needs of the public." 2 In moderating the debate between competing expert opinions at the trial level, Pitfield J finds that " [t] $\mathrm{he}$ correlation between Dr. Marsh's opinion and reality is reflected in the circumstances of the [individual] plaintiffs." ${ }^{3}$ I think that these type of statements are in part a reflection of the various judges' attempts to engage with problems of evidence and proof, with the question of how we know when "law" connects to "reality" in some appropriate way. ${ }^{4}$

The question of connections and disconnections is made quite explicit in the section 7 aspect of the Insite case. Part of this analy- 
sis requires the court to determine whether the impugned drug possession and trafficking laws are "overbroad" or "arbitrary" as they relate to the activities of the users and staff of the safe injection site. This requires direct consideration of the alleged connections between the objectives of the law and its consequences in the social reality in which it operates. Thus, in examining the constitutional question of what kind of connection is required to make the law legitimate, judges also engage with the evidentiary question of what will count as proof of such connection.

Central to these questions is the notion of the burden of proof. In Insite, there is no doubt, as a matter of law, that the claimants carry the burden of proof. PHS, Dean Wilson and Shelley Tomic must provide evidence to persuade the court, on a balance of probabilities, that their characterization of the impugned legislation is the right one. The judgments of the B.C. Supreme Court and the Court of Appeal in Insite on the question of arbitrariness are framed quite directly in terms of the burden of proof: for Rowles JA there was "ample" evidence to ground the trial judge's finding of arbitrariness, whereas for Smith JA this issue was characterized by a "lack of evidence." 5 For Smith JA, the claimants simply did not meet their burden of proof. However, the notion of the burden of proof is most useful when taken beyond the quantitative: it is not simply a matter of "more" or "less" evidence.

I suggest that the full meaning of a burden of proof becomes quite complex in the context of constitutional litigation, particularly when it involves the rights of individuals and communities who are marginalized in Canadian political and legal discourse. Beyond the simple determination that constitutional claimants carry the burden of proof, many related questions linger about the factual background judges should use to contextualize the evidence before them, about the proper roles for expert opinion and personal testimony, and about access to resources for generating useful evidence and presenting it to the court. All of these affect the distribution of burdens and benefits in the judge's determination of the facts. I think it is useful to read the judgments on arbitrariness in Insite through this lens because it helps to explain what is important and interesting about the case, and also because it provokes some questions for further thinking about the meaning of the burden of proof.

The judges' differing perspectives on the adequacy of the evidence on arbitrariness relates in part to the way each judge contextualizes that evidence. I believe that the determination of the appropriate context for understanding and evaluating evidence is a complex and significant one. In this comment, I start to think through three aspects of this determination: 1) the question of whether the community or reference should be a local or national one; 2) the question of how the evidence of the individual claimants should be understood; and 3) the role of community consensus.

When answering questions about the connection between the law and its communities, judges must decide which communities are the relevant ones for understanding the facts of the case. In their decisions, Pitfield $J$ and Rowles JA both orient their analysis to the local and provincial communities which are most affected by Insite and the competing laws surrounding them. At the trial level, Pitfield $\mathrm{J}$ finds that the impugned legislation is indeed arbitrary in the way it operates in the context of Insite and the Downtown Eastside of Vancouver (DTES). He says that "[i]nstead of being rationally connected to a reasonable apprehension of harm, the blanket prohibition contributes to the very harm it seeks to prevent. It is inconsistent with the state's interest in fostering individual and community health, and preventing death and disease." The objectives of the law are measured against its consequences for local communities.

At the Court of Appeal, Rowles JA finds that the trial judge's conclusion on this matter is "amply supported by the evidence."7 Rowles JA also finds that the concept of harm reduction is a constituent part of Parliament's objective in enacting the $C D S A,{ }^{8}$ further supporting her view that the application of the legislation arbitrarily undermines its own ob- 
jectives in the context of Insite. ${ }^{9}$ Rowles JA also goes further, saying that the legislation, when applied in this context, has no salutary effect. Thus, the rights of the claimants are affected "without any ameliorating benefit to those persons or to society at large."10

Locating the dispute squarely in the provincial and local community affects Rowles JA's constitutional analysis, but it also has consequences for her approach to the evidence and the burden of proof. Placed in this context, the evidence establishing that Insite does reduce harm from drug use, including the risk of fatal overdose, firmly supports the claim about arbitrariness: a law which aims to promote health and safety but instead promotes disease and risk of death is arbitrary indeed. In this way, the claimants have discharged their burden of proof by providing personal experience and expert opinion which shows that Insite prevents harm.

In her dissenting judgment, Smith JA finds that the claimants in the case have not offered sufficient evidence to demonstrate that the impugned parts of the CDSA are arbitrary. In particular, she holds that it is insufficient for establishing arbitrariness to show that one consequence of the legislation is inconsistent with its purpose. ${ }^{11}$ Thus, even if it is true that the prohibition of access to safe injection sites causes harm or increases the risk of death for injection drug users, this alone is not enough to make the entire law inconsistent with the state's objective in protecting health. ${ }^{12}$

In contrast to Pitfield J and Rowles JA, Smith JA identifies the local or provincial focus of the evidence as a source of weakness and partiality. Smith JA does not directly take issue with the conclusion that the operation of the CDSA may increase harm, including the risk of death, to injection drug users in the DTES. However, "if the broader state interest in the health and public safety of all Canadians (not just the intravenous drug users) becomes the focus of the analysis, it cannot be said that the evidence supports the conclusion that section 4(1) of the CDSA bears no relation to or is inconsistent with these broader interests, or even that the prohibition as it applies to addicts is not necessary to protect these interests." ${ }^{\prime \prime 3}$ So, for Smith JA, the burden of proof borne by the claimants is not discharged, because they have not provided evidence about the effects of the law on communities beyond the DTES, or the alternatives that might have been available to Parliament to fulfill its objectives.

If we think about the burden of proof as doing substantive work in relation to justice, the question of sufficient evidence might be reframed as follows: In the context of litigation about the rights of marginalized people, what are the obligations of a judge when deciding on a community of reference? The choice about framing the evidence at the local or national level resonates with competing notions of federalism, and these values are part of what animates the outcome. When the litigation involves the lives and rights of marginalized and vulnerable communities, as it does in Insite, values of equality also come into play. How does the introduction of equality values assist in determining how we should understand the burden of proof in this context?

One way to respond to equality values in the context of the burden of proof would be to say that the court carries an obligation to attempt to place the evidence of a marginalized claimant in a context which gives it meaning, to imagine a world in which that person's claims make sense. I think we can see the various judges grappling with this possibility in relation to their treatment of the evidence of the individual claimants in the case.

Pitfield $\mathrm{J}$ sets out the evidence of the two personal claimants, Dean Edward Wilson and Shelly Tomic. Their affidavit evidence, as reported in the decision, describes some aspects of their personal histories, their health, and their experiences with drugs and addiction. Ms. Tomic's affidavit, for example, states that she was born addicted to speed due to her mother's addiction during pregnancy, and that her first experience with illegal drugs occurred when she was seven years old. ${ }^{14} \mathrm{Mr}$. Wilson's affidavit describes his long-term addiction to both cocaine and heroine, and his 
participation in more than 25 treatment programs over the past 37 years. ${ }^{15}$

Pitfield J notes that Canada did not challenge the evidence of either individual. ${ }^{16}$ However, the consequence of their evidence in the decisions is not entirely transparent, and does not explicitly enter into the analysis on arbitrariness. At the trial level, Pitfield $\mathrm{J}$ states that the evidence of Mr. Wilson and Ms. Tomic provides a lens for interpreting the evidence of the expert witnesses. Specifically, in favouring to some extent the evidence of the plaintiff's expert, Pitfield J finds that "[t]he correlation between Dr. Marsh's opinion and reality is reflected in the circumstances of the [individual] plaintiffs." 17

At the B.C. Court of Appeal, Rowles JA writes that the evidence of the personal complainants is part of what "reveals the impact of the application of sub-section 4(1) of the $C D S A$ on addicted persons in the DTES and how that is related to addicted persons engaging in unsafe practices, which result in overdoses and the spread of infectious diseases and other harms." ${ }^{.18}$ Rowles JA thus relies on the evidence of the personal complainants to support her conclusion that the trial judge was correct in finding that the legislation did engage section 7 interests in life, liberty and security of the person.

In her dissenting judgment that there was insufficient evidence to find that the laws in question offended section 7, Smith JA invokes the evidence of the individual complainants to support Canada's claims about the significance of the state objective in this case. She writes that "the evidence regarding ... the difficult lives of Mr. Wilson and Ms. Tomic speaks directly to the addictive and dangerous nature of the drugs." 19

These passages suggest to me that while the evidence of the individual claimants is taken quite seriously by all of the judges, Pitfield J and Rowles JA allow this evidence to play a larger role in grounding the way they see the evidence as a whole. In those judgments, it seems that the world in which the claimants' evidence makes sense is used to test the other evidence, including determining which expert evidence is the more persuasive and relevant. This approach makes the failings of the impugned legislation central, rather than marginal. Rather than re-imagining a world in which the claimants' lives are marginal to Canadian public life, interpreting the burden of proof through an equality lens has the potential to place their reality at the heart of the analysis.

The questions of how the evidence should be placed in context also engages the issues of controversy, consensus and democracy that arise throughout this case. Although the litigation indicates strong differences of opinion between the provincial and federal governments, Rowles JA writes that she doubts the accuracy of Canada's "assertion that the operation of Insite is controversial in a policy sense. In this province, there is no longer any serious debate about the need for Insite as a health care facility." ${ }^{20}$ Both Rowles JA and Pitfield $J$ discuss the political processes that lead up to the establishment of Insite, and the development over time of a form of community consensus on this issue. In contrast, the judgment of Smith JA prioritizes the actions of Parliament, which are of course also linked to democratic processes of a different kind.

These questions about the role of community consensus might speak to the burden of proof by generating reasons for preferring one context over another. In the context of rights claims by marginalized communities and the existence of a broad political process, perhaps our understanding of the burden of proof should allow us to privilege a factual framework which has been used to support that consensus. Rather than saying, as Smith JA does, that absent evidence from the claimants about options other than a blanket prohibition, Parliament's claims about the law must be "taken at face value," 21 we might require more powerful actors such as the federal government to demonstrate why its view of the situation should prevail over a worldview which provides cohesion to the process of community discourse which has lead to consensus. 
Understanding the burden of proof as a substantive matter of equality and justice opens far more questions than it answers and I suggest that the answers to these questions will never be obvious and may not even be attainable. However, I do think that asking these questions is a useful exercise. In the Insite case, thinking about how the evidence is contextualized in the local or national community, or within or without the experiences of individual claimants and in support or against processes of community consensus, directs our attention to the relationship between the burden of proof and the possibility for justice. The value of the "connection" between law and its communities depends on how we build it.

\section{Notes}

* Ph.D. Candidate, Faculty of Law, University of British Columbia.

1 PHS Community Services Society $v$ Canada (Attorney General), 2008 BCSC 661, 293 DLR $\left(4^{\text {th }}\right)$ 392 [BCSC], rev'd 2010 BCCA 15, 314 DLR $\left(4^{\text {th }}\right)$ 209 [BCCA], leave to appeal to SCC granted, 33556 (June 24, 2010). The decisions are jointly referred to here as the "Insite" case.

2 BCCA, ibid at para 172 [emphasis added].

3 BCSC, supra note 1 at para 59 [emphasis added].

4 The nature of this connection might be understood in various ways: objective, constitutive, related to power, etc.

5 BCCA, supra note 1 at para 75, Rowles JA, majority and para 291, Smith JA, dissenting.

$6 \quad$ BCSC, supra note 1 at para 152.

7 BCCA, supra note 1 at para 75.

8 RSC 1996, c 19 [the CDSA].

9 BCCA, supra note 1 at paras 71-72.

$10 \quad$ Ibid at para 76.

$11 \quad$ Ibid at para 288.

$12 \quad$ Ibid at para 291.

$13 \quad$ Ibid at para 287.

14 BCSC, supra note 1 at para 65.

15 Ibid at paras 61-62.

$16 I$ Ibid at para 60.

17 Ibid at para 59 [emphasis added].

18 BCCA, supra note 1 at para 35.

$19 \quad$ Ibid at para 280.

$20 \quad$ Ibid at para 62.

$21 \quad$ Ibid at para 297. 